de-Valleyfield, Quebec, that captures 10 metric tons of $\mathrm{CO}_{2}$ per day. Crucially, the enzyme allows them to use smaller temperature swings to absorb and release $\mathrm{CO}_{2}$. "Compared with other industrial-scale carbon capture systems, that means we have the lowest capture cost right now," says Louis Fradette, chief technology officer of $\mathrm{CO}_{2}$ Solutions.

The success of bio-based CCU systems will ultimately depend on economics, says Michael Carus, head of the Nova Institut in Hürth, Germany, an interdisciplinary research center, which organized the Essen conference. "They are not price-competitive yet-but the same is true of biofuels," he says.

At the conference, delegates discussed what sort of market incentives might pull the technology into more widespread use. For example, mandatory quotas to blend aviation fuel with $5 \%$ of fuel from CCU sources would create a valuable market to help fledgling businesses. "That would be a big step, because the aviation industry has no idea how to reduce its $\mathrm{CO}_{2}$ emissions," says Carus.

Even so, Tuck Seng Wong, a CCU researcher at the University of Sheffield, UK, thinks these approaches are still preferable to pumping waste $\mathrm{CO}_{2}$ into porous rock formations deep underground to capture and retain excess carbon. CCU plants can pay for themselves through the chemicals they produce. In contrast, burying $\mathrm{CO}_{2}$ deep underground "is analogous to sweeping the problem under the carpet."

Mark Peplow Cambridge, UK

\title{
Sexed-up beer
}

One Belgian laboratory's Friday evening beer fest has ended with a paper describing how to inject flavor into lagers by encouraging some sexual action between yeasts. Kevin Verstrepen, Stijn Mertens and collaborators at VIB laboratory for Systems Biology in Leuven showed with genetic studies that most lager fermentation results from a hybrid species of two parent yeastsSaccharomyces cerevisiae, and S. eubayanus. Because these two species are so different, crossing them to make more diverse lagers has been unsuccessful. At least, so far. The researchers describe how they optimized growing conditions to foster mating between the two yeasts, which resulted in hundreds of new lager strains (Appl. Environ. Microbiol., doi:10.1128/AEM.02464-15, 25 September 2015). Of the 31 they tested in small-scale beer fermentors, only 10 performed well in terms of fermentation speed and flavor. Two, in particular, fermented even faster and produced novel aroma profiles compared with commercially available lager yeasts.

\section{First Rounders Podcast:}

\section{William Rutter}

Bill Rutter is founder, chairman and CEO of Synergenics, which manages a consortium of biotech companies. He was also a founder of Chiron and is credited with bringing the University of California at San Francisco to its prominent position in life sciences research. His discussion with Nature Biotechnology covers building out the labs at UCSF, sequencing the hepatitis $C$ virus and his short stint in the Navy.

http://www.nature.com/nbt/podcast/index.html

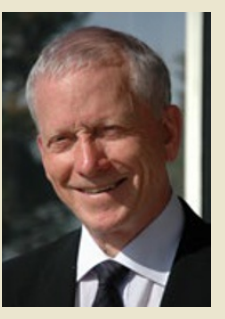

